\title{
Breastfeeding, Oral Habits and Malocclusions in the Childhood: A Literature Review
}

\author{
Fernanda Matias de Carvalho', Lidia Audrey Rocha Valadas'1,*, Joseph Anderson Sá Nogueira', Patrícia Leal Dantas Lobo', Fernanda \\ Leal Dantas Sales Pimentel ${ }^{2}$, Marina Sena Lopes da Silva Sacchetto ${ }^{3}$, Emmanuel Arraes de Alencar Júnior ${ }^{1}$, Arkila Pinheiro Rodrigues de \\ Sousa', Sarah Gabrielle Sousa de Oliveira Rodrigues ${ }^{4}$, Pollyanna Bitu de Aquino ${ }^{5}$ \\ 'Federal University of Ceará, Fortaleza, BRAZIL. \\ ${ }^{2}$ State University of Ceará, Fortaleza, BRAZIL. \\ ${ }^{3}$ Federal University of Piauí, Teresina, BRAZIL. \\ ${ }^{4}$ Assis Chateaubriand Maternity School- MEAC, Fortaleza, Ceará, BRAZIL. \\ ${ }^{5}$ Christus University Center, Fortaleza, BRAZIL.
}

\begin{abstract}
To review in the literature the relationship between lactation, deleterious bucal habits and malocclusion. For this literature review, scientific articles were searched in databases such PubMed and SciELO, in English and Portuguese languages. The search initially resulted in a total of 63 published studies, where 33 were selected, published in the period between 1991 and 2020. In this literature it has been observed that studies on breastfeeding and deleterious bucal habits have a lot of controversy, however, there are several studies that show an inverse association between the time of natural breastfeeding and the deleterious habits, thus suggesting that the feeding method in infants can influence the growth and correct development of the stomatognathic system. It is concluded
\end{abstract}

that deleterious bucal habits are associated with malocclusions, especially anterior open bite and crossbites. Early diagnosis and intervention may prevent future disorders and orthodontic problems for patients. Key words: Breast Feeding, Habits, Malocclusion, Primary dentition.

Correspondence

Dr. Lidia Audrey Rocha Valadas,

Federal University of Ceará, Fortaleza, BRAZIL.

Email id: lidiavaladas@gmail.com

DOI: 10.5530/jyp.2022.14.5

\section{INTRODUCTION}

Malocclusion is defined as an alteration in growth and development that affects the dental arches, the facial skeleton or both, and is considered a public health problem, as it has a high prevalence and possibility of prevention and treatment, which may negatively affect quality of life. The etiology is multifactorial and may be due to genetic factors, dental and facial trauma, deleterious and nutritional habits, among others. ${ }^{1,2}$

The growth and development of the stomatognathic system and, consequently, dental occlusion can be influenced by several factors such as breathing, breastfeeding, chewing, sucking habits (digital, bottle and/ or pacifiers) and swallowing. This health problem has received increasing attention, as it occupies the third highest prevalence among oral diseases, being inferior only to caries and periodontal disease. ${ }^{2,3}$

The involvement of children by malocclusions has been associated with the previous establishment of harmful oral habits such as bruxism, onychophagia, mouth breathing, bottle, non-nutritive sucking (finger, pacifier); these, in turn, have their etiology linked, probably, to a period of unsatisfactory breastfeeding or for a short period of time..$^{2,3}$

Research on factors related to malocclusion is important to describe and analyze indicators of occlusal problems in this way, as these problems can compromise dental esthetics and cause functional disorders in the stomatognathic system, pain, psychosocial problems, in addition to a greater susceptibility to occlusal trauma, caries and periodontal disease. ${ }^{4}$ The present work seeks to review in the literature the relationship between interferences in the development of occlusion in childhood, analyzing the form of breastfeeding with the installation of harmful habits and, based on these, the development of malocclusion.

\section{METHODOLOGY}

For this literature review, the electronic search for scientific articles was performed using the PubMed (including Medline and PubMed Central), LILACS and SciELO database, with articles published between 1991 and 2020, in English and Portuguese languages. Initially, the studies were selected through the analysis of titles and abstracts, as described above. Then, full texts of the most relevant studies were reviewed and selected. The search initially resulted in a total of 64 published studies. Of these studies, 31 were excluded for not presenting the full text or being suitable for the review proposal.

\section{LITERATURE REVIEW}

\section{Breastfeeding and child oral health}

The importance of breastfeeding for the child's full growth and development is a consensus among health professionals. Breast milk, in addition to being considered the best and most complete food from a nutritional point of view, reinforces the baby's immunity, playing an important role against infant mortality. At the same time, the functions performed through breastfeeding favor the adequate development of facial structures, as they promote adequate neural stimuli for bone and muscle growth capable of preventing malocclusions due to underdevelopment. $^{5}$

It is very important to know and use the definitions of breastfeeding adopted by the World Health Organization (WHO) and recognized worldwide. When breastfeeding takes place directly at the breast, it is called natural, when it occurs through the use of bottles it is called artificial and when both are used, it is called mixed breastfeeding ${ }^{5}$ 
WHO and the Ministry of Health recommend exclusive breastfeeding for six months and supplemented for up to two years or more. It is considered that the ideal period for the introduction of complementary foods is after the sixth month of life, since before this period, breast milk is able to supply all the child's nutritional needs. In addition, in the sixth month of life, the child has already developed the necessary reflexes for swallowing, such as the tongue reflex, already showing excitement at the sight of food, already supporting the head, facilitating the feeding offered by spoon, and there is the beginning of the eruption of the first teeth, which facilitates chewing. ${ }^{2,3}$

According to Köhler, ${ }^{6}$ the act of natural breastfeeding leads the baby to perform from 2,000 to 3,500 mandibular milking movements, while in artificial feeding the sucking movements are only from 1500 to 2000. Therefore, in breastfeeding, the baby expands its stimulation of the sensory oral motor system, as the muscle strength required for the flow of milk during the milking process will be much greater in relation to bottle-feeding.

\section{Breastfeeding and harmful habits}

The effects of breastfeeding on the orofacial system have produced many studies, reporting a close relationship between breastfeeding time and harmful habits, ending up with malocclusions. Thus, deleterious oral habits are installed more frequently in children who did not have natural breastfeeding. When the child is being bottle-fed, the flow of milk is much greater than that of natural breastfeeding, so the child is nutritionally satisfied in less time and with less effort. Emotional ecstasy in relation to the sucking impulse is not reached and the child looks for substitutes such as a finger, a pacifier and objects to satisfy himself. ${ }^{7-9}$

Sousa et al. ${ }^{8}$ through a study carried out in the city of João Pessoa-PB with 126 children aged 2 to 6 years old, concluded that the insufficient duration of natural breastfeeding was associated with the presence of oral habits.

Carrascoza et al. ${ }^{5}$ in their study, followed for 120 days mothers and babies up to six months of age participating in a breastfeeding program. It was observed that in the sample served that $87.50 \%$ of babies were being exclusively breastfed until the first month of life and at the end of the sixth month only $47.50 \%$. There was a relationship between a greater use of pacifiers in children who were not exclusively breastfed.

In the study by Miotto et al. ${ }^{10}$ which evaluated the relationship between early weaning and the presence of harmful oral habits in children aged three to five years in Vitória/ES, they showed that children weaned early were four times more likely to develop the habit of using pacifiers. In this research, $12.4 \%$ of the children had the habit of digital sucking and $37.7 \%$ had the habit of using a pacifier. Among children, almost $2 / 3$ of those who used pacifiers did not have exclusive natural breastfeeding until the end of the second month.

\section{Deleterious Oral Habits (HBDs)}

Oral habits are classified as physiological (functional) and nonphysiological, also called deleterious or parafunctional. Physiological habits are defined as those that contribute to the establishment of normal occlusion and favor the release of the potential for facial growth in all its fullness. When oral functions constitute potential etiological factors in the deterioration of occlusion and alteration of the normal pattern of facial growth, they are considered deleterious oral habits. ${ }^{11,12}$

It is believed that parafunctional oral habits can interfere with the growth and development of the stomatognathic system, due to an imbalance between external and internal muscle forces, leading to possible bone deformations. Practically all children practice some type of deleterious oral habit, however individual predisposition, frequency and intensity artfactors that will modulate the impairment of the orofacial muscles, craniofacial growth and occlusal alterations. When they last between three to five years, usually anterior open bite is a consequence. ${ }^{12,13}$

Corrêa $^{13}$ estimates that genetic factors contribute about $40 \%$ of its influence to the future determination of normality, harmony and facial beauty and that the other $60 \%$ of what will happen to the child's face, in its long and continuous growth process and development, will depend on its interaction with the environment, which includes way of life, harmful habits, respiratory/allergic diseases, food texture, way of eating.

\section{Finger Suction Habits}

Finger sucking is a natural reflex for babies, they start sucking on their thumbs or fingers when they are still inside the uterus. This habit is a mechanism for relieving tension and obtaining a feeling of pleasure. Compared to pacifier suction, digital suction is more harmful, as the finger exerts greater pressure on the oral cavity and is always more accessible. ${ }^{14-16}$

However, if the finger-sucking habit persists beyond the time of onset of eruption of permanent teeth, the result may be a malocclusion characterized by separate, projected upper incisors; lingual positioning of the lower incisors; anterior open bite; narrower upper dental arch and floor and deep palate vault, due to the disorder in the force system in the naso-maxillary complex, making it impossible for the nasal floor to establish normal vertical growth. The following can also be established: canine Class II relationship; distal step molar relationship; posterior crossbite, labral incompetence; increased tongue pressure and speech defects. Among all the effects caused by suction, anterior open bite is the most common malocclusion. ${ }^{17-19}$

Antunes et al. ${ }^{20}$ evaluated the relationship of breastfeeding forms with deleterious oral habits and their effect on occlusion in the primary dentition of 443 children between 2 and 6 years of age. In this study, an association between the type of breastfeeding and finger sucking was observed $(p=0.04)$, and the main related malocclusions were anterior open bite, posterior crossbite and accentuated overjet.

\section{Pacifier Sucking Habits}

The use of pacifiers is a common childhood habit throughout the world and there is no consensus among health professionals regarding its use. The pacifier can play an important role in sucking, as the baby has a strong need for sucking, which is not always satisfied by nutritious sucking. In some cases, when the child is premature and does not have complete suction development, this is only achieved around the $32^{\text {nd }}$ week of pregnancy, many Pediatricians advise the use of pacifiers to help in the baby's oral motor development. ${ }^{21,22}$

The pacifier sucking habit is described as a physiological need of the newborn, due to the sucking instinct, as a substitute for the maternal breast in a non-nutritive situation, with the objective of calming the baby. With tooth eruption, this need decreases. This habit is quite prevalent and has a strong cultural character, which may, over time, cause malocclusions. ${ }^{23}$

A study carried out in the city of Bauru-SP pointed out that pacifier sucking is a risk factor for malocclusion of greater intensity than digital sucking. ${ }^{24}$ In the study by Garbin et al. ${ }^{23}$ the use of pacifiers was the most prevalent deleterious oral habit among the others, where $44.8 \%$ of the sample used it.

To minimize future problems with these practices, the pacifier must be orthodontic, that is, with an anatomical shape, which adapts perfectly to the child's oral cavity, adjusting to the palate and tongue, better distributing forces during the suction movement. Zardetto ${ }^{25}$ concluded that children who used pacifiers with orthodontic nipples presented less 
alterations in the dental arches and oral myofunctional structures than those who used a conventional pacifier.

\section{Bottle Sucking Habits}

It is known that many children do not have the chance to be breastfed, in these cases the bottle appears as a viable solution to provide adequate nutrition. medical criterion. ${ }^{2}$

Important care is regarding the type of nozzle and orifice size. It is recommended to use anatomic nipples, also called orthodontic nipples, which have the smallest orifice, as the child should only receive milk, and not other foods through the bottle. The size of the nipple must be compatible with the size of the baby's oral cavity and must be made of silicone. $^{13}$

In the study by Miotto et al. ${ }^{26}$ the prevalence of anterior open bite and its relationship with harmful oral habits, such as bottle-feeding, were evaluated in 150 children aged between 3 and 5 years. The prevalence of anterior open bite was $16 \%$ and within this sample there was a statistically significant relationship with children who used baby bottles.

Soares-Maffei et al. ${ }^{27}$ evaluated harmful oral habits in 101 children aged 2 to 11 years, where all children used a bottle at some time in their lives. A total of $33 \%$ of the evaluated children who were weaned before 6 months and used a bottle, $64 \%$ had malocclusion.

\section{Onychophagy}

Onychophagia is the habit of biting the nails, however, undesirable chewing habits include everything that is done without the nutritional objective, such as chewing a pencil or pen cap, biting the lip and/or cheek. The etiology suggested by Corrêa ${ }^{14}$ includes stress, imitation of other family members, heredity, transference of sucking habits and lack of care in treating nails and cuticles.

The main associated complications are: cuticle wounds and bleeding at the edges of the nails, deformities in the fingers, fungal or bacterial infections, root resorption, fractures at the edges of the teeth and gum lesions. ${ }^{21}$ However, from an orthodontic point of view, onychophagia combined with the habit of biting pencils or other objects can be the cause of bad dental positions, the malocclusion associated with these habits are, therefore, of a more localized nature. ${ }^{18}$

The presence of onychophagy is hardly found in children under 3 years of age, but there are records of 18-month-old children with the habit already installed. Between 3 and 6 years of age, there is a significant increase in the occurrence of the habit, remaining stable from 7 to 10 years of age. There is an increase from 10 years of age onwards, with its maximum incidence among adolescents and decreasing with age. ${ }^{14}$

Silva, ${ }^{28}$ investigating the relationship between malocclusions and deleterious oral habits in patients treated in Campina Grande-PB, observed in $55.36 \%$ of the sample composed of children with malocclusion between 4 and 12 years of age, the presence of oral habits deleterious, among these the most prevalent was onychophagia (23.21\%).

\section{Bruxism}

Bruxism is a parafunction that can affect children and adults. Some individuals clench their teeth while awake, characterizing daytime bruxism, and others grind their teeth while sleeping, developing nighttime bruxism. Bruxism is the most complex habit in terms of etiology, and its causes are not clear. Toledo ${ }^{29}$ suggests that the etiology of bruxism is multifactorial, with its possible causes classified as of origin: local, systemic, psychological and occupational.

There is a great discrepancy in the literature regarding the data on the prevalence of bruxism. In Brazil, in Belo Horizonte-MG, Serra-Negra, ${ }^{7}$ in a cross-sectional epidemiological study, evaluated 652 children aged between 7 and 10 years old belonging to public and private schools, finding the prevalence of this bruxism habit in $35.3 \%$ of the sample.

Bisinélli ${ }^{30}$ evaluated the occurrence of bruxism in children between 2 and 12 years of age with and without harmful oral habits. The results showed that among children with sucking habits, a total of $22.58 \%$ had centric bruxism and $45.16 \%$ eccentric bruxism, whereas those without sucking habits $(8.82 \%)$, only one had centric bruxism. The study found that most children had some kind of deleterious habit, and more than half of the children had bruxism, predominantly eccentric.

\section{Mouth breathing}

Breathing is a reflex mechanism that installs itself in the first moment of life. Physiological breathing is performed only through the nasal cavities when there is a total clearance of the upper airways. Air flows freely and the individual must keep their lips closed and in gentle contact. ${ }^{31}$

The presence of an impediment to nasal breathing may generate a pattern of oral supplementation and, if this is installed during the development period, it may determine several alterations that significantly affect this system. Such alterations can appear together or isolated, the individuals that they present are considered to have Mouth Breather Syndrome characterized by: presence of dark circles, expressionless look, poorly developed zygomatic bone, lack of development of the middle third of the face, high palate and atresia maxillary, posterior mandible rotation, posterior and anterior open crossbite, gingivitis, tonsils and adenoids hypertrophy, labial incompetence, labial and lingual hypotonia and inadequate body and head posture. ${ }^{21}$

Imbaud et al. $^{3}$ evaluated the relationship between mouth breathing, malocclusion and orofacial alterations in patients undergoing treatment for malocclusion correction. A total of 89 patients were evaluated and a statistical relationship was found between nasal breathing and cephalometric alterations $(p=0.009)$.

\section{DISCUSSION}

Breast milk through exclusive natural breastfeeding is the main food for the growth and development of babies, and it is not limited only to nutritional and immunological benefits, but also neurological, emotional, development of the stomatognathic system and also in relation to speech due to stimulation of suction. There is a consensus that the breast is the best means of feeding the baby, and that alternative methods that use bottles and cups do not replace this means. It is known that the maintenance of natural breastfeeding stimulates the exercise of the perioral muscles, thus influencing the correct development of the stomatognathic system. Due to muscle fatigue, the baby does not feel the need for a second type of suction, unlike what occurs in artificial breastfeeding, which does not require the same effort, and generates an imbalance in the development of orofacial muscles and the baby tends to have other harmful habits such as finger sucking, pacifier, etc. ${ }^{5,912,32}$

According to studies by Cavalcanti; Medeiros-Bezerra and Moura ${ }^{14}$ it was noticed that the lowest frequency of parafunctional oral habits occurred in children who received natural breastfeeding, confirming the theory that breastfeeding satisfies the baby's sucking needs, due to the effort exerted during breastfeeding, also satisfying the psycho-emotional needs of the child who does not look for other means to supply him. In the study by Pires ${ }^{32}$ it was found that babies breastfed for a period of at least 12 months had better chewing and perioral muscle function when compared to babies breastfed for a shorter period.

Amary et al. ${ }^{11}$ state that if the habit is performed until the age of 2 years, there should not be any clinical concern, since any habit that lasts for more than three years or is quite frequent will be harmful and can cause serious malocclusions. . Cavalcanti; Medeiros-Bezerra and Moura, ${ }^{14}$ 
Sousa et al. ${ }^{8}$ argue that the persistence of HBDs in children over 3 years of age significantly increases the probability that the dental arch will present undesirable occlusal characteristics in primary dentition. Tomita et al. ${ }^{24}$ report the self-correction of malocclusion after the cessation of oral habits, which are considered physiological up to the age of 2 to 3 years, and state that the persistence of habits after 3 years of age is considered a child behavior of regression.

When associating the presence of oral habits with the existence of malocclusions, no statistically significant relationship was found, according to the study by Amary, ${ }^{11}$ which showed that $50 \%$ of children who did not use oral habits had occlusal alterations. It is known that the presence of these alterations does not only depend on the installation of harmful habits, but also on the characteristics of each child, such as genetic and environmental factors that influence it.

With regard to malocclusions, it is known that, even though there is a consensus that the term normal occlusion can be applied to a wide range of conditions existing in primary dentition, some studies report the difficulty in performing comparative analysis, due to the heterogeneity of criteria and classifications adopted. ${ }^{24}$ The study design, sampling and method of analyzing the results may also be contributing to the large discrepancy in available data on different populations, in addition to differences in ethnic and sociodemographic nature.

In the study by Tomita et al. ${ }^{24}$ who evaluated the relationship between socioeconomic determinants and oral habits of risk for malocclusion in preschool children in the city of Bauru-SP, socioeconomic indicators such as education, residence and income did not influence the development of HBD. There are several causes of malocclusions, and the importance of natural breastfeeding as a source of food for their prevention is a fact. Finally, Abate et al. ${ }^{33}$ in a systematic review points out that breastfeeding is a factor that seems to reduce malocclusion, with a positive relationship between the duration of breastfeeding months and lower risk. However, the authors point out the need for more longitudinal research with periodic clinical evaluation in different dentitions.

\section{CONCLUSION}

Based on the revised literature, it was observed that there are controversies regarding the characteristics of malocclusions, however, there is a consensus that there is a strong inverse relationship between the duration of natural breastfeeding and the presence of deleterious oral habits and malocclusions. Studies show that the prevalence of nonnutritive sucking habits in children with malocclusion is high, especially the pacifier. It is concluded that deleterious oral habits are associated with malocclusions, especially anterior open bite and crossbite. Early diagnosis and intervention can prevent future inconvenience and orthodontic problems for patients.

\section{CONFLICT OF INTEREST}

The authors declare that there is no conflict of interest.

\section{REFERENCES}

1. Dimberg L, Lennartsson B, Bondemark L, Arnrup K. Oral Health-related qualityof-life among children in Swedish dental care: The impact from malocclusions or orthodontic treatment need. Acta Odontol Scand. 2016;74(2):127-33. doi: 10.3109/00016357.2015.1059485, PMID 26206412.

2. Santos JG. Prevalência de maloclusões e associação com hábitos de sucção em pré-escolares do município de Florianópolis. Monografia (Graduação). Curso de Odontologia. Florianópolis: Centro de Ciências da Saúde, Universidade Federa de Santa Catarina. 60 p; 2015. Available from: https://repositorio.ufsc.br/xmlui/ handle/123456789/156715 [cited 20/1/2022]

3. Imbaud TCS, Mallozi MC, Domingos VBTC, Solé D. Frequency of rhinitis and orofacial disorders in patients with dental malocclusion. Rev Paul Pediatr. 2016;34(2):184-8. doi: 10.1016/J.rpped.2015.10.002, PMID 26631324

4. Pinto RMS. Maloclusão e necessidade de tratamento ortodôntico. Available from: https://sigarra.up.pt/ffup/pt/pub_geral.show_file?pi_gdoc_id=716971 [dissertação] (Mestrado Integrado). Salazar: Mestrado Integrado em Medicina Instituto de Ciências Biomédicas Abel. Porto: Universidade do Porto. 42 p; 2015.

5. Carrascoza KC, Possobon RdF, Ambrosano GMB, Costa Júnior ÁL, Moraes ABAd. Fatores determinantes do uso de chupeta entre criancas participantes de programa de incentivo ao aleitamento materno. Rev CEFAC. 2014:16(2):582-91. doi: 10.1590/1982-021620149712.

6. Köhler NRW. Distúrbios miofuncionais: considerações sobre seus fat ores etiológicos e conseqüências sobre o processo de crescimento/desenvolvimento da face. Rev Dent Press Ortodont Ortop Fac. 2000;3(5):66-79.

7. Serra-Negra JMC, Crianças Be. Reações interna e externa dos sujeitos. Available from: http://www.bibliotecadigital.ufmg.br/dspace/bitstream/handle/1843/ ZMRO-7EMPJC/tese_j_nia_serra_negra.pdf?sequence=1 [tese] (Doutorado). Doutorado em Odontologia. Belo Horizonte: Faculdade de Odontologia da Universidade Federal de Minas Gerais. 70 p; 2006.

8. Sousa FRN, Taveira GS, Almeida RVD, Padilha WWN. O Aleitamento materno e sua relação com hábitos bucais deletérios e maloclusão dentária. Pesq Bras Odontopediatr Clín Integr. 2004;4(3):211-6.

9. Chen X, Xia B, Ge L. Effects of breast-feeding duration, bottle-feeding duration and non-nutritive sucking habits on the occlusal characteristics of primary dentition. BMC Pediatr. 2015:15:46. doi: 10.1186/s12887-015-0364-1, PMID 25895651.

10. Miotto MHMdB, Cavalcante WS, Godoy LM, Campos DMKdS, Barcellos LA Prevalência de mordida aberta anterior associada a hábitos orais deletérios em crianças de 3 a 5 anos de Vitória, ES. Rev CEFAC. 2014;16(4):1303-10. doi: 10.1590/1982-021620142213.

11. Amary ICM, Rossi LAF, Yumoto VA. assen cio-. Ferreira VJ, Marchesan $I Q$. Hábitos deletérios: alterações de oclusão. Rev CEFAC. 2002;4(2):123-6.

12. De Oliveira IM, Conde-Júnior AM, De Sousa Cavalcante MMA, Soares da Silva AB, Rizzo MDS, Leite CMDC. Saberes maternos sobre a relação da Amamentação natural e hábitos Bucais Deletérios. J Health Scie. 2016:18(2):75-9. doi: 10.17921/2447-8938.2016v18n2p75-79

13. Correa MSNP. Odontopediatria na primeira infância. 2ed. São Paulo: Editora Santos; 2005

14. Cavalcanti AL, Bezerra PKM, Moura C. Aleitamento natural, aleitamento artificial, hábitos de sucção e Maloclusões em pré-escolares Brasileiros. Rev Salud Publ. 2007;9(2):194-204

15. American Dental Association. Thumb sucking and pacifier use. J Am Dent Assoc. 2007;138(8):1176.

16. Bona AP, Moreira KMS, Tedesco TK, Imparato JCP, Ferreira BD, Reis JB. Abordagem multidisciplinar de mordida aberta anterior associada à sucção digital: caso clínico. Rev APCD. 2016;70(1):58-63.

17. Kennedy GE. From the ape's dilemma to the wealing's dilemma: Early weaning and its evolutionary context. J Hum Evol. 2005;48(1):123-45.

18. Moyers RE. Ortodontia. $4^{\text {th }}$ ed. Rio de Janeiro: Guanabara Koogan; 1991

19. Proffit W, Fields H. Ortodontia contemporânea. 2ed. Rio de Janeiro: Guanabara Koogan; 1995.

20. Antunes LS, Teixeira EC, Gomes IF, Almeida MH, Mendes PP, Antunes LAA. Avaliação da relação causal entre a presença de hábitos Bucais Deletérios, tipo de aleitamento e Maloclusões em crianças na dentadura decídua. Unopar Cient Ciênc Biol Saúde. 2015;17(2):75-80.

21. Guedes-Pinto AC, Bönecker $M$, Rodrigues CRMD. Fundamentos de odontologia: Odontopediatria. 1ed. São Paulo: Editora Santos; 2009.

22. Lobo PLD, Marques LARV, Lobo Filho HG, Lotif MAL, Melo CCSA, Rodrigues Neto EM. Associação entre o uso da chupeta e a diminuição do risco de morte súbita em bebês. Full Dent Sci. 2016;7(27):190-4.

23. Garbin CAS, Garbin AJI, Martins RJ, Souza NP, Moimaz SAS. Prevalence of non-nutritive sucking habits in preschoolers and parents' perception of its relationship with malocclusions. Cien Saúde Colet. 2014;19(2):553-8. doi: 10.1590/1413-81232014192.23212012, PMID 24863831.

24. Tomita NE, Bijella VT, Franco LJ. Relação entre hábitos bucais e má oclusão em pré-escolares. Rev Saúde Pública. 2000;34(3):299-303. doi: 10.1590/S0034 89102000000300014.

25. Zardetto CGDC, Rodrigues CRMD, Stefani FM. Effects of different pacifiers on the primary dentition and oral myofunctional strutures of preschool children. Pediatr Dent. 2002;24(6):552-60. PMID 12528948

26. Miotto MHMB, Rossi FJ, Barcellos LA, Campos DMKS. Prevalência da mordida aberta anterior em crianças de 3 a 5 anos. Arq Odontol. 2016;52(2):111-6.

27. Soares-Maffei M, Souza RS, Mello AS, Souza JGMV, Boleta DCF. Relação do desmame precoce com hábitos bucais deletérios na primeira infância. Odontol Clin-Cient. 2016;15(4):253-8.

28. Silva AL. Prevalência das oclusopatias e hábitos bucais deletérios em pacientes atendidos na Clínica de Ortodontia da Universidade Estadual da Paraíba. Campina Grande: Universidade Estadual da Paraíba. 17 p; 2013. Monografia (graduação). Curso de odontologia. Available from: http://dspace.bc.uepb.edu. br/jspui/handle/123456789/5193 [cited 20/1/2022].

29. Toledo AO, Bezerra ACB. Odontopediatria: Fundamentos para a prática clínica. 2nd ed. São Paulo: Ed. Premier; 1996. p. 319-25. 
30. Bisinélli FG. Ocorrência de bruxismo em crianças com hábitos orais deletérios. Monografia (Graduação). [Curso de Fonoaudiologia da Universidade Federal de Santa Catarina. Florianópolis, SC; 2015.59 p]. Available from: https://repositorio. ufsc.br/handle/123456789/133463 [cited 20/1/2022].

31. Bueno SB, Bittar TO, Vazquez Fde L, Meneghim MC, Pereira AC. Association of breastfeeding, pacifier use, breathing pattern and malocclusions in preschoolers. Dental Press J Orthod. 2013;18(1):30.e1-6. doi: 10.1590/s217694512013000100006. PMID 23876964.
32. Pires SC. Influência da duração do aleitamento na qualidade da função mastigatória em crianças pré-escolares. Available from: https://www. lume.ufrgs.br/bitstream/handle/10183/55157/000855416. pdf? sequence $=1$ [dissertação] (Mestrado). Porto Alegre: Faculdade de Medicina, Universidade Federal do Rio Grande do Sul. 111 p; 2012.

33. Abate A, Cavagnetto D, Fama A, Maspero C, Farronato G. Relationship between breastfeeding and malocclusion: A systematic review of the literature. Nutrients. 2020;12(12):3688. doi: 10.3390/nu12123688, PMID 33265907.

Article History: Received: 15-11-2021; Revised: 03-12-2021; Accepted: 13-01-2022

Cite this article: Carvalho FM, Rocha L, Nogueira JAS, Lobo PLD, Pimentel FLDS, Sacchetto MSLS, Sousa APR, Chagas FO, Rodrigues SGSO, Silva RA, Tizzo GR,

Amorim PS, Aquin PB. Relationship Between Breastfeeding, Deleteric Bucal Habits and Malocclusions in the Childhood. J Young Pharm. 2022;14(1):25-9. 